\title{
Compositionally and functionally distinct editosomes in Trypanosoma brucei
}

\author{
ASWINI K. PANIGRAHI, ${ }^{1}$ NANCY LEWIS ERNST, ${ }^{1}$ GONZALO J. DOMINGO, ${ }^{1,3}$ MICHELE FLECK, \\ REZA SALAVATI, ${ }^{1,2,4}$ and KENNETH D. STUART ${ }^{\mathbf{1 , 2}}$ \\ ${ }^{1}$ Seattle Biomedical Research Institute, Seattle, Washington 98109, USA \\ ${ }^{2}$ Department of Pathobiology, University of Washington, Seattle, Washington 98195, USA
}

\begin{abstract}
Uridylate insertion/deletion RNA editing in Trypanosoma brucei mitochondria is catalyzed by a multiprotein complex, the $\sim 20 S$ editosome. Editosomes purified via three related tagged RNase III proteins, KREN1 (KREPB1/TbMP90), KREPB2 (TbMP67), and KREN2 (KREPB3/TbMP61), had very similar but nonidentical protein compositions, and only the tagged member of these three RNase III proteins was identified in each respective complex. Three new editosome proteins were also identified in these complexes. Each tagged complex catalyzed both precleaved insertion and deletion editing in vitro. However, KREN1 complexes cleaved deletion but not insertion editing sites in vitro, and, conversely, KREN2 complexes cleaved insertion but not deletion editing sites. These specific nuclease activities were abolished by mutations in the putative RNase III catalytic domain of the respective proteins. Thus editosomes appear to be heterogeneous in composition with KREN1 complexes catalyzing cleavage of deletion sites and KREN2 complexes cleaving insertion sites while both can catalyze the $U$ addition, $U$ removal, and ligation steps of editing.
\end{abstract}

Keywords: RNA editing; editosome; endonuclease; RNase III

\section{INTRODUCTION}

Most trypanosome mitochondrial mRNAs undergo posttranscriptional editing by the insertion and deletion of uridylates (Us) at multiple sites. Editing is catalyzed by multiprotein complexes, editosomes that sediment at $\sim 20 \mathrm{~S}$, although larger complexes have also been reported (for reviews, see Madison-Antenucci et al. 2002; Simpson et al. 2004; Stuart et al. 2005). Complexes that were purified from Trypanosoma brucei by various methods were reported to contain at least seven proteins (Rusché et al. 1997), and our lab initially identified 16 of what now appear to be at least 20 proteins (Panigrahi et al. 2001a, b, 2003). Some of the corresponding Leishmania tarentolae editosome proteins have been experimentally identified (Aphasizhev et al. 2003a). By comparative sequence analyses the orthologs of $T$. brucei editosome proteins have been identified in Trypanosoma cruzi and Leishmania major genome data-

Present addresses: ${ }^{3}$ Program for Appropriate Technology in Health (PATH), Seattle, WA 98107, USA; ${ }^{4}$ McGill University, Institute of Parasitology, Quebec H9X 3V9, Canada.

Reprint requests to: Kenneth D. Stuart, Seattle Biomedical Research Institute, 307 Westlake Avenue N, Suite 500, Seattle, WA 98109, USA; e-mail: ken.stuart@sbri.org; fax: (206) 256-7229.

Article published online ahead of print. Article and publication date are at http://www.rnajournal.org/cgi/doi/10.1261/rna.45506. bases (Worthey et al. 2003). The proposed unified nomenclature system for editosome proteins that is applicable across the species (Stuart et al. 2005) will be used here.

Most editosome proteins occur as pairs or sets with sequence and/or motif similarities (Panigrahi et al. 2003). The functions of several of these proteins have been demonstrated by biochemical and/or genetic means. These include the two related RNA editing ligases KREL1 and KREL2 (McManus et al. 2001; Panigrahi et al. 2001a; Rusché et al. 2001; Schnaufer et al. 2001). Genetic and biochemical analyses have shown that KREL1 is essential for editing and cell survival and is associated with RNA ligation during deletion editing. KREL2 is not essential for editing or cell survival, although it is associated with RNA ligation during insertion editing (Huang et al. 2001; Rusché et al. 2001; Schnaufer et al. 2001; Cruz-Reyes et al. 2002; Drozdz et al. 2002; Schnaufer et al. 2003). Thus, it has been proposed that KREL1 can compensate for KREL2 in vivo, but not vice versa. Two TUTases, KRET1 and KRET2, have been identified. KRET2 is an integral part of the $20 \mathrm{~S}$ editosome and catalyzes $U$ insertion to pre-mRNA. KRET1 is in a separate complex and is involved in guide RNA maturation, and both the enzymes are essential for editing and for cell growth (Aphasizhev et al. 2002, 2003b; Ernst et al. 2003). Exonuclease function has been demonstrated for 
recombinant KREX1 (LC-2) protein of Leishmania, and down-regulation of its ortholog in T. brucei (KREPC1/TbMP100) affects RNA editing, complex stability, and cell growth (Kang et al. 2005). Its related protein KREX2 (KREPC2/TbMP99) is associated with exonuclease activity (Schnaufer et al. 2003; Kang et al. 2005). The editosome protein KREPA3 (TbMP42), which has two zinc fingers and an OB-fold (Panigrahi et al. 2001b; Schnaufer et al. 2003), has been reported to be essential for cell growth and editing along with evidence that it has exonuclease and endonuclease activities (Brecht et al. 2005). However, the observed cleavage activity of KREPA3 may not be specific to editing, and two recent studies from our laboratory using gene inactivation or exclusive expression of a mutated version in vivo of KREN1 (KREPB1/TbMP90) and KREN2 (KREPB3/TbMP61) RNase III proteins showed that they are required for deletion and insertion cleavage, respectively (Carnes et al. 2005; Trotter et al. 2005).

Biochemical and genetic analyses have generated a partial protein-protein interaction map (Schnaufer et al. 2003). It was shown that KREPA1 interacts with KRET2 and KREL2, forming a trimeric complex that catalyzed the coordinated $\mathrm{U}$ addition and ligation steps of insertion editing. Similarly, KREPA2 was found to interact with KREX2 and KREL1, and the trimeric complex catalyzed the $\mathrm{U}$ removal and ligation steps of deletion editing. KREPA1 and KREPA2 are essential for RNA editing, cell survival, and appear not to have direct catalytic function, but they may have roles in substrate interaction and coordination of the order of the catalytic steps (Drozdz et al. 2002; Huang et al. 2002; O'Hearn et al. 2003; Schnaufer et al. 2003; Kang et al. 2004). The loss of KREPB5 results in loss of editosomes, and thus it is required for the structural stability and perhaps assembly of 20 S editosomes (Wang et al. 2003).

While the 20S editosomes directly catalyze the editing process, other proteins and complexes have been identified that perform functions associated with editing, such as the KRET1 complex (Aphasizhev et al. 2002, 2003b). A complex that contains MRP1 (gBP21) and MRP2 (gBP25) catalyzes a matchmaking type of RNA annealing and has been proposed to facilitate base-pairing between gRNAs and pre-mRNAs (Müller et al. 2001). Down-regulation of expression of MRP2 alone or together with MRP1 inhibits cell growth and differentially alters the abundance of edited RNAs, as well as RNAs that do not undergo editing (Vondruskova et al. 2005). These effects resemble the consequence of down-regulation of expression of the RNAbinding protein, RBP16 (Pelletier and Read 2003). The RNA-binding protein REAP1 has also been suggested to have a role in editing (Madison-Antenucci and Hajduk 2001). Thus editing appears to be a dynamic process that involves interactions among multiple proteins and complexes.

The studies herein describe the composition and functions of $20 \mathrm{~S}$ editosomes or subcomplexes thereof that were purified via tagged KREN1, KREPB2 (TbMP67), or KREN2 proteins that contain RNase III motifs. They reveal differential composition of editosomes with mutually exclusive presence of these three proteins. The functions of these complexes in vitro as well as those containing KREN1 or KREN2 with point mutations indicate a segregation of the insertion and deletion endonuclease activities. These results indicate compositional and functional heterogeneity of $20 \mathrm{~S}$ editosomes at least with respect to these three RNase III proteins.

\section{RESULTS}

\section{Identification of additional editosome proteins}

The related KREN1, KREPB2, and KREN2 proteins, which contain U1-like zinc fingers, RNase III motifs, and doublestranded RNA binding motifs (dsRBM) with the greatest sequence conservation in the RNase III motifs (Panigrahi et al. 2003; Worthey et al. 2003), had TAP-tags placed at their $\mathrm{C}$ terminus (Fig. 1A). T. brucei cell lines were created that express each of these TAP-tagged proteins under the control of a tetracycline-inducible promoter. The TAPtagged complexes were sequentially affinity-purified by IgG Sepharose and Calmodulin affinity columns as described

A

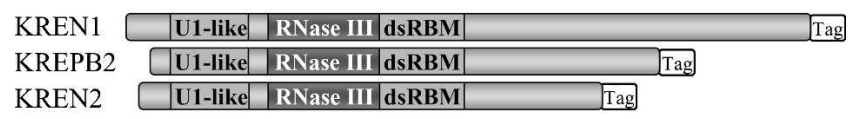

B

C

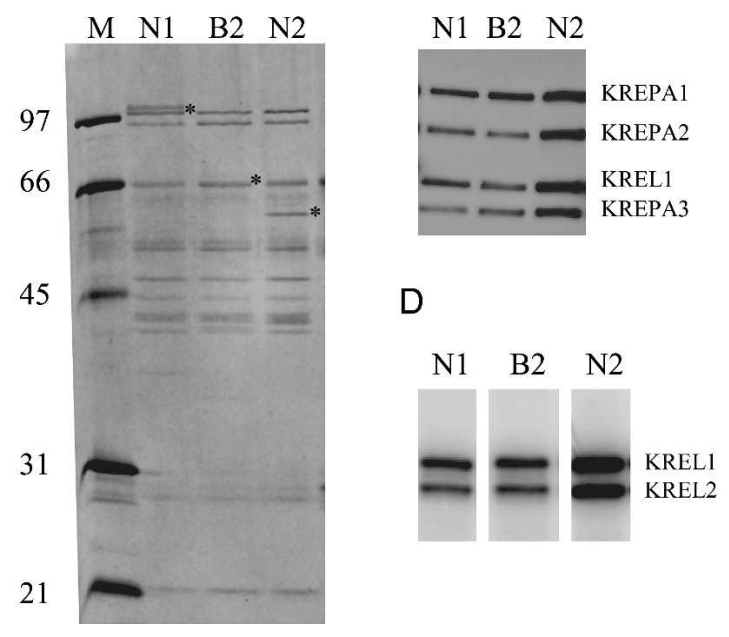

FIGURE 1. T. brucei editosomes with TAP-tagged RNase III proteins. (A) Diagram showing the positions of the motifs and the tags. $(B)$ SYPRO Ruby stained SDS-PAGE gel of TAP-tag purified complexes. The tagged proteins are indicated with an asterisk in the lanes with KREN1 (N1), KREPB2 (B2), and KREN2 (N2) samples, and the molecular weights of the protein size standards $(\mathrm{M})$ are indicated. $(C)$ Western analysis of samples from $B$ using monoclonal antibodies specific for KREPA1, KREPA2, KREL1, and KREPA3 editosome proteins. (D) SDS-PAGE gel of adenylated proteins in samples from $B$ showing the presence of KREL1 and KREL2. 
in Materials and Methods (Rigaut et al. 1999). Western analysis of cell lysates using the PAP (Peroxidase- AntiPeroxidase) reagent showed that the tagged proteins were expressed in vivo, and the cells expressing the tagged proteins divided at normal rate compared with parental cell lines (data not shown). The protein profiles of the purified tagged complexes in SYPRO Ruby stained SDSPAGE gels were similar although some differences were apparent (Fig. 1B). Western analysis using monoclonal antibodies showed the presence of editosome component proteins KREPA1, KREPA2, KREL1, and KREPA3 (Fig. 1C), and KREL1 and KREL2 were demonstrable by the adenylation assay (Fig. 1D) in all the three isolated tagged complexes. Thus tagged KREN1, KREPB2, and KREN2 were incorporated into editosomes of the expected size and with a largely normal protein complement.

Three additional editosome proteins were identified by mass spectrometric analyses of the purified complexes. The mass spectrometric data from TAP-tagged complexes and those acquired in earlier studies (Panigrahi et al. 2003) from editosomes isolated by immunoaffinity chromatography using a monoclonal antibody specific for KREPA2 and by column chromatography were compared with the most recent $T$. brucei sequence database to identify the proteins present in the purified complexes (Table 1). Proteins with predicted preprocessed molecular weights of 19,41 , and $47 \mathrm{kDa}$ were identified in at least two editosome preparations. The $19-\mathrm{kDa}$ protein has $30 \%$ sequence identity and 47\% similarity to KREPA6 (Fig. 2A) and is designated as KREPA5. KREPA5 corresponds to T. brucei ORF Tb08.12O16.250 (http://www.genedb.org). While the original annotation in the GeneDB database predicted translation initiation at the second Met codon, we detected the peptide VTMVGAMHDIQVGFLDR that includes this Met (underlined), indicating that initiation is upstream at the first Met codon. The protein sequence is predicted to have a mitochondrial localization signal. The $47-$ and $41-\mathrm{kDa}$ proteins correspond to Tb09.160.4130 and Tb08.26E13.370 ORFs in the GeneDB database, respectively. They contain $\mathrm{N}$-terminal U1-like zinc finger motifs and thus are grouped with other proteins containing a U1-like zinc finger motif and are designated KREPB7 and KREPB8 (Stuart et al. 2005; A. Schnaufer, unpubl.). These two proteins share $21.5 \%$ identity and $34.3 \%$ sequence similarity (Fig. 2B). The difference between these proteins is largely due to insertions of 22 and 27 amino acids in KREPB7 relative to KREPB8. KREPB6 was identified in complexes isolated by tagging other editosome component proteins (Stuart et al. 2005; A. Schnaufer and R. Salavati, unpubl.). The presence of these proteins in complexes that were purified by different methods and their similarities to known editosome proteins indicate that they are components of the $20 \mathrm{~S}$ editosomes. The orthologs of KREPA5, KREPB7, and KREPB8 were identified in $T$. cruzi genome database (http://www.genedb.org) by homology searches. In L. major genome database, the orthologs of KREPB7 and KREPB8 were identified by homology searches, and the ortholog of KREPA5 was identified by syntenic alignment.

\section{Differential composition and functions of tagged RNase III editosomes}

All known editosome proteins except KREPB6 were detected in complexes that were biochemically purified. Somewhat similarly, all known editosome proteins, except KREPB6, B7, and B8, were detected in complexes that were immunoaffinity-purified with a monoclonal antibody specific for KREPA2. While in aggregate 18 of the known editosome proteins were detected in the purified tagged RNase III protein complexes, characteristic proteins were not detected in each of the purified complexes (Table 1). Notably, KREPB2 and KREN2 proteins were not detected in the KREN1 complex, nor KREN1 and KREN2 in the KREPB2 complex, nor KREN1 and KREPB2 in the KREN2 complex. In addition, KREPB8 but not KREPB7 was detected in the KREN1 complex, and, reciprocally, KREPB7 but not KREPB8 was detected in the KREN2 complex, while neither KREPB7 nor KREPB8 were detected in the KREB2 complex. Furthermore, both KREX1 and KREX2 were detected in the KREN1 complex, but KREX1 was not detected in the KREPB2 nor KREN2 complexes. KREPA5 was not detected in the KREPB2 complex and KREH1 was not detected in any of the three RNase III complexes nor in complexes purified using tagged KREL1 (Panigrahi et al. 2003). These data suggest that the tagged RNase III protein complexes have characteristically different compositions.

The different tagged RNase III editosomes have different catalytic properties in vitro (Fig. 3). The purified tagged KREN1, KREPB2, and KREN2 complexes all catalyzed precleaved deletion and precleaved insertion editing (Fig. $3 \mathrm{~A}, \mathrm{~B})$. Thus, these complexes all have exonuclease and deletion editing-associated RNA ligase activities as well as TUTase, and insertion editing-associated RNA ligase activities, consistent with their protein content (Table 1). Using modified full-round assays that were designed to enhance the detection of endonuclease cleavage products (see Materials and Methods), the tagged KREN1 complex was found to cleave the editing site of the A6 pre-mRNA deletion substrate but not the editing site of the A6 premRNA insertion substrate (Fig. 3C,D). It also catalyzed U removal and ligated the product; the latter was presumably due to the adenylation of some ligase since ATP was not added, thus resulting in edited product. Conversely, the tagged KREN2 complex cleaved the substrate at the insertion editing site but not at the deletion editing site. No cleaved product was detected with either substrate using the tagged KREPB2 complex. No apparent differences in the amount of in vitro deletion endonuclease activity were detected in the 20S fractions of the cells expressing TAP-tagged 
TABLE 1. Proteins identified in editosomes by mass spectrometry

\begin{tabular}{|c|c|c|c|c|c|c|}
\hline Proteins & Function & Tag-N1 & Tag-B2 & Tag-N2 & A2-IP & SP-Q-S6 \\
\hline KREPA1 (MP81) & Interaction & $\sqrt{ }$ & $\sqrt{ }$ & $\sqrt{ }$ & $\sqrt{ }$ & $\sqrt{ }$ \\
\hline KREPA2 (MP63) & Interaction & $\sqrt{ }$ & $\sqrt{ }$ & $\sqrt{ }$ & $\sqrt{ }$ & $\sqrt{ }$ \\
\hline KREPA3 (MP42) & Interaction & $\sqrt{ }$ & $\sqrt{ }$ & $\sqrt{ }$ & $\sqrt{ }$ & $\sqrt{ }$ \\
\hline KREPA4 (MP24) & Interaction & $\sqrt{ }$ & $\sqrt{ }$ & $\sqrt{ }$ & $\sqrt{ }$ & $\sqrt{ }$ \\
\hline KREPA5 (MP19) & Interaction $^{\mathrm{a}}$ & $\sqrt{ }$ & N.D. & $\sqrt{ }$ & $\sqrt{ }$ & $\sqrt{ }$ \\
\hline KREPA6 (MP18) & Interaction $^{\mathrm{a}}$ & $\sqrt{ }$ & $\sqrt{ }$ & $\sqrt{ }$ & $\sqrt{ }$ & $\sqrt{ }$ \\
\hline KREN1 (MP90) & Endonuclease & $\sqrt{ }$ & N.D. & N.D. & $\sqrt{ }$ & $\sqrt{ }$ \\
\hline KREPB2 (MP67) & Endonuclease $^{a}$ & N.D. & $\sqrt{ }$ & N.D. & $\sqrt{ }$ & $\sqrt{ }$ \\
\hline KREN2 (MP61) & Endonuclease & N.D. & N.D. & $\sqrt{ }$ & $\sqrt{ }$ & $\sqrt{ }$ \\
\hline KREPB4 (MP46) & Interaction ${ }^{\mathrm{a}}$ & $\sqrt{ }$ & $\sqrt{ }$ & $\sqrt{ }$ & $\sqrt{ }$ & $\sqrt{ }$ \\
\hline KREPB5 (MP44) & Interaction & $\sqrt{ }$ & $\sqrt{ }$ & $\sqrt{ }$ & $\sqrt{ }$ & $\sqrt{ }$ \\
\hline KREPB6 (MP49) & Interaction $^{\mathrm{a}}$ & N.D. & N.D. & N.D. & N.D. & N.D. \\
\hline KREPB7 (MP47) & Interaction $^{\mathrm{a}}$ & N.D. & N.D. & $\sqrt{ }$ & N.D. & $\sqrt{ }$ \\
\hline KREPB8 (MP41) & Interaction $^{\mathrm{a}}$ & $\sqrt{ }$ & N.D. & N.D. & N.D. & $\sqrt{ }$ \\
\hline KREX1 (MP100) & Exonuclease & $\sqrt{ }$ & N.D. & N.D. & $\sqrt{ }$ & $\sqrt{ }$ \\
\hline KREX2 (MP99) & Exonuclease & $\sqrt{ }$ & $\sqrt{ }$ & $\sqrt{ }$ & $\sqrt{ }$ & $\sqrt{ }$ \\
\hline KREL1 (REL1) & RNA ligase & $\sqrt{ }$ & $\sqrt{ }$ & $\sqrt{ }$ & $\sqrt{ }$ & $\sqrt{ }$ \\
\hline KREL2 (REL2) & RNA ligase & $\sqrt{ }$ & $\sqrt{ }$ & $\sqrt{ }$ & $\sqrt{ }$ & $\sqrt{ }$ \\
\hline KRET2 (RET2) & TUTase & $\sqrt{ }$ & $\sqrt{ }$ & $\sqrt{ }$ & $\sqrt{ }$ & $\sqrt{ }$ \\
\hline KREH1 (mHel61p) & Helicase & N.D. & N.D. & N.D. & $\sqrt{ }$ & $\sqrt{ }$ \\
\hline
\end{tabular}

TAP-tagged KREN1 (Tag-N1), KREPB2 (Tag-B2), and KREN2 (Tag-N2) complexes were isolated by sequential IgG and Calmodulin affinity chromatography. The other complexes were purified by immunoaffinity chromatography using a monoclonal antibody specific for KREPA2 (A2-IP) or by biochemical methods using sequential SP Sepharose, Q Sepharose, and Superose 6 column chromatography (SP-Q-S6) (Panigrahi et al. 2003). $\sqrt{ }$ indicates protein identified; N.D. indicates not detected by mass spectrometry.

a Putative function.

KREN1 or KREN2 proteins compared with their respective uninduced cell lines (results not shown).

\section{The RNase III domain is required for KREN1 and KREN2 catalytic activities}

Two conserved amino acids at corresponding positions in the RNase III motif, and which have been shown to be critical for RNase III catalytic activity in other organisms (Worthey et al. 2003), were mutated in the three RNase III proteins in order to assess the effect on editing. $\mathrm{E}_{271}, \mathrm{E}_{197}$, and $E_{227}$ were mutated to $V$, as were $G_{277}, G_{203}$, and $G_{233}$ in KREN1, KREPB2, and KREN2, respectively (Fig. 4A). The cells divided at a normal rate upon expression of mutant proteins, except a slower growth phenotype was observed in KREN1 after $96 \mathrm{~h}$ (results not shown). Western and adenylation analyses of purified tagged mutant KREN1 and KREPB2 complexes detected editosome proteins KREPA1, KREPA2, KREL1, KREPA3, and KREL2 (Fig. 4B,C). However, analyses of the purified tagged mutant KREN2 complexes showed presence of KREPA1, KREPA3, and KREL2, but not KREPA2 or KREL1. Mass spectrometric analysis of the purified tagged mutant complexes identified peptides from the CBP tag in all cases and peptides containing the point mutations in KREPB2 and KREN2, confirming the presence of both the tag and the mutated protein in the purified samples. All of the proteins identified in wild-type tagged KREN1 and KREPB2 complexes were also identified in tagged mutant KREN1 and tagged mutant KREPB2 complexes, respectively. In contrast, only seven proteins-KREPA1, KREPA3, KREPA6, KREN2, KREPB4, KREL2, and KRET2were identified in tagged mutant KREN2 complex. 20S editosomes are present in the tagged mutant KREN2 expressing cell line (result not shown) and probably contain wild-type KREN2 (from untagged endogenous alleles). Thus, the composition of the tagged mutated KREN1 and KREPB2 complexes were indistinguishable from wild-type tagged complexes as assayed. However, half of the proteins are absent from the tagged mutated KREN2 complexes, indicating that its $E_{227}$ and/or $\mathrm{G}_{233}$ residues function in the association of KREN2 with 20S editosomes while this does not appear to be the case for corresponding residues in tagged KREN1 or KREPB2 20S editosomes.

The purified tagged mutant KREN1 complexes did not catalyze endonucleolytic cleavage of the deletion editing site in contrast to the complexes with the wild-type protein (Fig. 4C) and did not catalyze cleavage of an insertion editing site as previously observed (data not shown; Fig. 3D). Similarly, purified tagged mutant KREN2 complexes did not catalyze cleavage of the insertion editing site unlike purified tagged complexes with wild-type protein (Fig. 4D) and did not cleave a deletion editing site (data not shown; Fig. 3D). These data indicate that the purified tagged mutant complexes contain the mutated tagged protein but not wild-type protein. They also provide confirmatory evidence in vitro supporting the results from in vivo genetic 
A

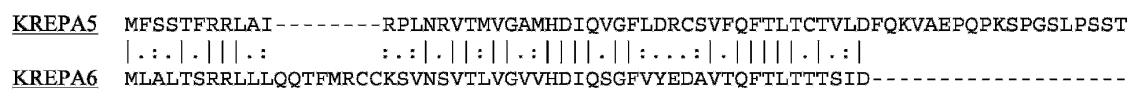

RTAPNPNGEEVEKHINKEQYTVRCLGSEAYTEALKNYLDDGCIVRVIGRLKTTEVVD - AGKKQPFPCI IVEQGRWSTVSLV

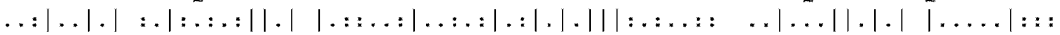
--TTHPTQEVV- - VEKDHHAIRCFG-ELFSAEVKQKVKEGNVVCVNGRLRLSPQLEPSCNKHFYFPYIQV-QPPHGQVAVI

HSLRK (amino acids 1-151)

$|\ldots|$ :

HGDRR (amino acids 1-135)

B

KREPB7 WVFRNPEWCDLCKEPVALWVN-HHGRKDHALMDMHYTQMMEYPRRWNPEEVLVAFFDELQLPVETYQRSYTCYE $|: \ldots \ldots||\cdot||:||: \ldots:| .|.:||\ldots: \ldots \ldots \ldots \ldots:|||: .|||| \ldots \ldots \ldots .|\ldots| \ldots: \mid .:$. KREPB8 WLDLKTGWCHLCOE PLGATMGVHIGDRDHTNLQYFLFLYAAHGRRWSSEEVLRSCLATAP-TVHNYATRHTTWA

RAH- - - -RNELYSMLVELEEAKMLYFGEPRNTYLHRMQG-GLRGMDHQGALVLHRYILGPFMRLYPNAHIQDFSNLVDFVT

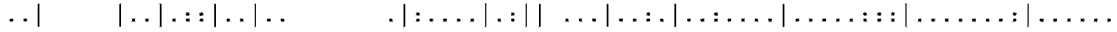
HLHVMDDARRALKALLFHLTH - . . . . - PPQQALSHVLQGRS PLGFWYSGERMWKLRISRLVTQVFPPISAGMMTNFTQKCW

CAYNMETVYDLCGFYTLDKVALKADYKPSSPAALGLGGIAVHSSPSHGFVONAAESQQQSRRASSTASTGSRSAADMDEEAF $\ldots|.| .:|| \quad|| .|\ldots| \ldots: \quad:|: \quad \ldots|:$. GRSNGERMYD -

SRKAVFVRQLLGQLRWLTLPCEEHPAGCKFPQHLMLLGEICLKYLVVEI IAARLCEYMVRVEPVW (amino acids 50-343) $.:|| .|||||| \quad|\ldots| \ldots|\ldots \ldots \ldots: \ldots| \quad: \ldots: .|: \ldots: \ldots|:|\ldots: \ldots||| .:|:|:$.

EKKAF FVRQLL- - - WELLSVEVRDEVDELTKH- --MADLALRRMAFEMI FLQSMEYMHKVQYVY (amino acids 115-347)

FIGURE 2. Sequence comparison between editosome proteins. (A) KREPA5 and KREPA6, (B) KREPB7 and KREPB8. The amino acid alignments indicate conserved (|), semiconserved (:), partially conserved (.).

analyses published recently from our laboratory (Carnes et al. 2005; Trotter et al. 2005) that the cleavage of the deletion editing site was catalyzed by KREN1 protein and that of the insertion editing site by KREN2 protein.

\section{Functional associations of KREN1 and KREN2}

Western analysis was performed on complexes from cells expressing TAP-tagged wild-type or mutant KREN1 that had been affinity-purified with an IgG column, released by TEV cleavage, and fractionated in high-resolution glycerol gradients as described in Materials and Methods. A mixture of MAbs against editosome proteins KREPA1, KREPA2, KREL1, and KREPA3 showed that most of the complexes from cells with tagged wild-type or mutant KREN1 sedimented around the $20 \mathrm{~S}$ region (Fig. 5A,B). As observed previously with TAP-tagged KREL1 or KREL2 (Schnaufer et al. 2003), partial complexes were detected in the 5-10S region of tagged KREN1, primarily with anti-KREPA1 antibody. Fractions were pooled from the 5 to $10 \mathrm{~S}$ and $20 \mathrm{~S}$ regions of the gradient and further purified by Calmodulin affinity chromatography. Western and adenylation analyses of the purified $20 \mathrm{~S}$ material revealed KREPA1, KREPA2, KREPA3, KREL1, and KREL2 in tagged wild-type and mutant complexes (Fig. 5C-F). The purified 5-10S wildtype material contained primarily KREPA1 and KREPA3, and KREL2 was detected by the more sensitive adenylation assay. In contrast, only a trace of KREPA1 and KREL2 was detected in the 5-10S material from the mutants.
The purified pooled $20 \mathrm{~S}$ material from the tagged wild-type KREN1 cells catalyzed precleaved deletion, precleaved insertion, and endonucleolytic cleavage of a deletion editing site but not of an insertion site (Fig. 5G-J). The pooled $\sim 20$ S material from the mutants catalyzed precleaved deletion and insertion editing, albeit with different relative abundance of the $\mathrm{U}$ addition, $\mathrm{U}$ removal, ligated, and edited products compared with the wild type but did not cleave either the deletion or insertion editing sites. The wild-type 5-10S material behaved similarly, although it contained more precleaved insertion than precleaved deletion editing activities (Fig. 5G,H) perhaps because there is proportionally more KREL2 than KREL1 in this sample (Fig. 5D). The $-4 \mathrm{U}$ product that accumulated with the mutant 5-10S material, of which only a small portion resulted in edited product, probably results from traces of ligase in this sample. Essentially no precleaved insertion or cleavage of either deletion or insertion sites occurred with the mutant material. Tagged KREN1 appears to be physically associated with a 5-10S insertion subcomplex based on the detection of KREPA1 by Western and KREL2 by adenylation but not KREPA2 and KREL1 that are components of the deletion subcomplexes. The presence of TUTase and ligase activities in these fractions is consistent with this conclusion, but $\mathrm{U}$ removal activity and deletion site cleavage activities were also detected.

Similar analyses showed that most of the wild-type tagged KREN2 complexes sedimented at $\sim 20 \mathrm{~S}$ with some sedimenting at 5-10S, which was comparable to the results with tagged KREN1 complexes as were the protein profiles of the purified complexes from the pooled $\sim 20 S$ and $5-10 S$ fractions (Fig. 6A,C,D). In contrast, most of the tagged mutant KREN2 complexes sedimented at 5-10S (Fig. 6B). KREPA1, KREPA3, and adenylatable KREL2 were identified in purified pooled 5-10S mutant KREN2 material, while traces of KREPA1 and adenylatable KREL2 were identified in $20 \mathrm{~S}$ fraction. Thus the amino acids that were mutated in the RNase III domain of KREN2 are important to editosome structural integrity.

The purified tagged wild-type KREN2 $\sim 20$ S complexes catalyzed the precleaved deletion and precleaved insertion editing activities, and cleaved an A6 pre-mRNA insertion editing site but not an A6 deletion editing site (Fig. 6G-J). The purified 5-10S KREN2 complexes from the wild-type and mutant cells catalyzed precleaved insertion, but not precleaved deletion editing sites; the mutant complexes did 
A

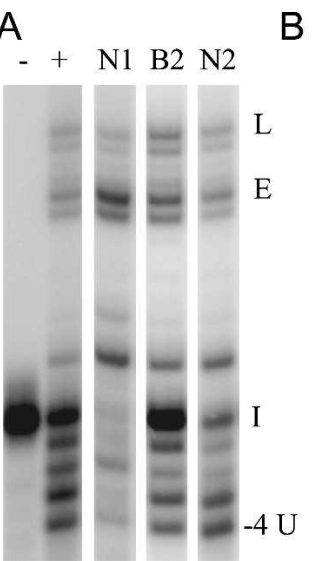

Pre-cleaved deletion

C

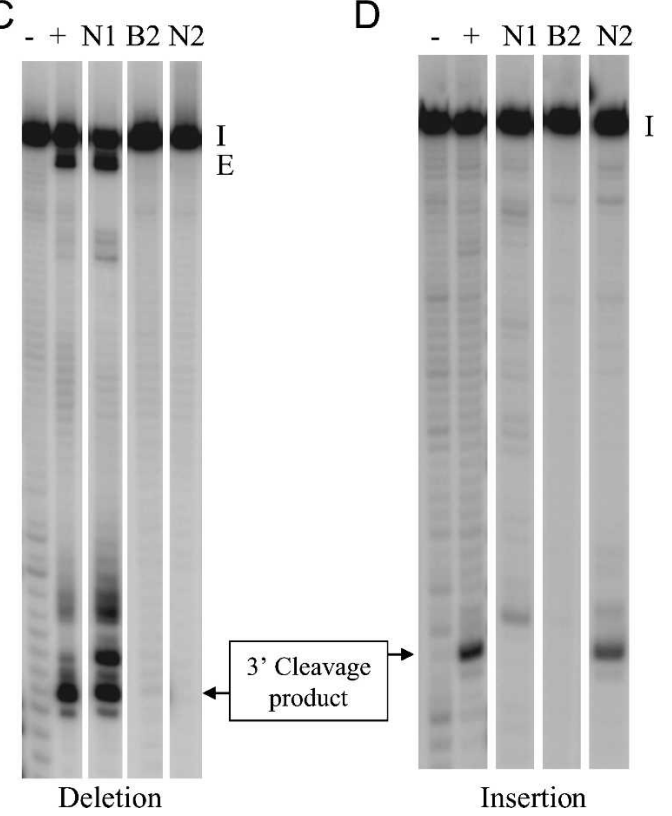

FIGURE 3. In vitro editing assays of tagged editosomes. Tagged KREN1 (N1), KREPB2 (B2), and KREN2 (N2) complexes and untagged $20 \mathrm{~S}$ editosomes that were purified by biochemical methods were assayed for precleaved deletion $(A)$ and insertion $(B)$ editing, which requires coordinated $\mathrm{U}$ removal and ligation, or $\mathrm{U}$ addition and ligation, respectively. They were also assayed for full-round deletion $(C)$ and insertion $(D)$ editing using a modified assay designed for the accumulation of endonucleolytic cleavage fragments. (See Materials and Methods for details.) Untagged editosomes with gRNA served as a positive control $(+)$ and, without gRNA, as a negative control $(-)$. Input labeled substrate RNAs (I) and unprocessed ligated input RNA (L) are identified, as are the products from which up to $4 \mathrm{U}$ 's were removed $(-4 \mathrm{U})$, up to 2 U's were added $(+2 \mathrm{U})$, result from endonucleolytic cleavage, or are edited by $\mathrm{U}$ deletion or insertion (E).

not cleave insertion nor deletion editing sites (Fig. 6G-J). Thus, KREN2 is functionally associated with insertion editing. Mass spectrometric analyses showed that the composition of the tagged KREN2 5-10S complex and mutated KREN2 5-10S complex is similar, except KREPB4 was not identified in wild-type 5-10S complex. The KREN2 5-10S complex contains KREPA1, KRET2, and KREL2 that are components of insertion subcomplex, and KREPA6 that interacts with both insertion and deletion subcomplexes (Schnaufer et al. 2003), and it also contains KREPA3 and KREN2. Thus KREPA3 and KREN2 are associated with an insertion editing subcomplex.

\section{DISCUSSION}

This study shows that the RNase III proteins KREN1 and KREN2 are functionally associated with separate complexes that catalyze deletion and insertion editing endonuclease activities, respectively, and that the RNase III domain is required for catalysis. The results also reveal that editosomes differ in composition, suggesting they are heterogeneous and possibly dynamic in composition in vivo.

\section{$20 S$ editosome proteins}

We previously identified 16 stable protein components of the core $20 \mathrm{~S}$ editosome, including the three RNase III

A

\begin{tabular}{|c|c|c|}
\hline & & $\mathrm{v}$ \\
\hline KREN1 & $\left(E_{271} V / G_{277} V\right)$ & RRVAFERLEYIGDNSWGNHLSNRMMLLFPD \\
\hline KREPB2 & $\left(E_{197} V / G_{203} V\right)$ & RSARFERSEMIGDNIVKVVVPDRLVRLFPA \\
\hline KREN2 & $\left(\mathrm{E}_{227} \mathrm{~V} / \mathrm{G}_{233} \mathrm{~V}\right)$ & $\begin{array}{l}\text { RSWEFERIEWIGDNVVKYVFNDRFNVIFPV } \\
*\end{array}$ \\
\hline
\end{tabular}

B

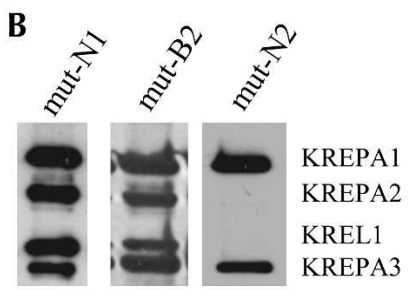

C

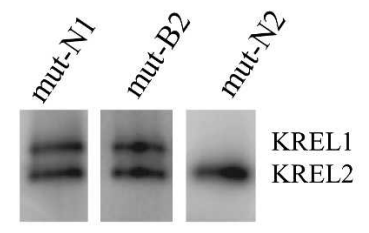

D

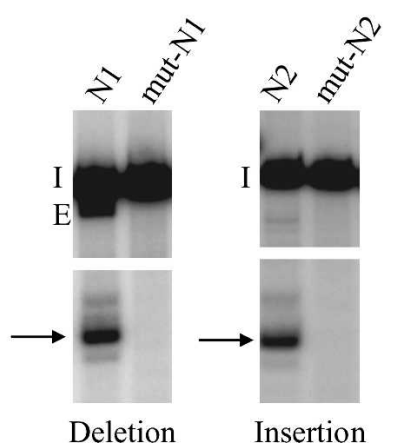

FIGURE 4. Tagged complexes containing mutated RNase III proteins. (A) Aligned RNase III domains KREN1, KREPB2, and KREN2 proteins showing the double mutations of conserved amino acids Glutamic acid (E) and Glycine (G) to Valine (V). (B) Western analyses of the purified mutant tagged complexes with a monoclonal antibody mixture specific for KREPA1, KREPA2, KREPA3, and KREL1. (C) Adenylation assays of the purified mutant complexes revealing KREL1 and KREL2. (D) Modified full-round editing assays (see Materials and Methods for details) that enhance detection of the $3^{\prime}$ cleavage products of editing endonuclease activity (arrow). 
A

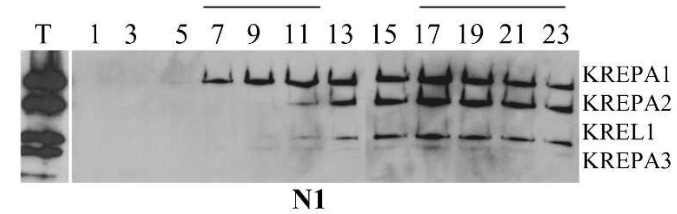

B

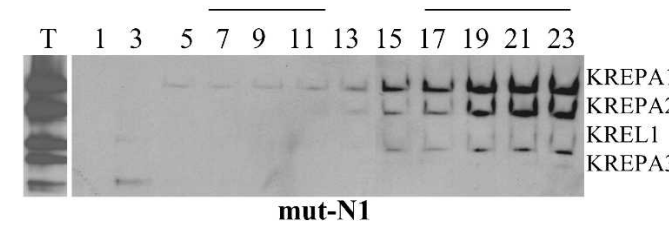

G

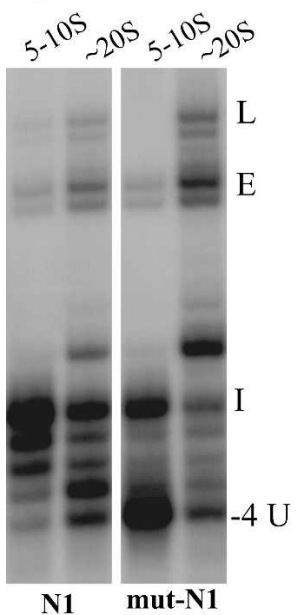

Pre-cleaved deletion

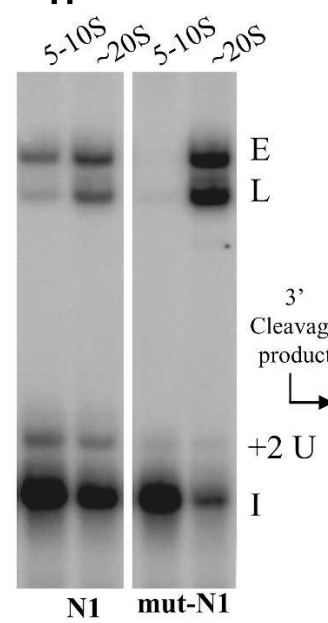

Pre-cleaved

insertion
C

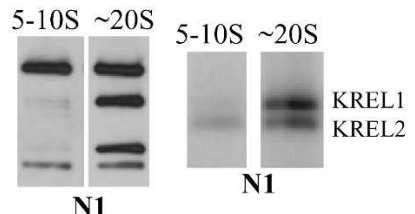

$\mathrm{E}$

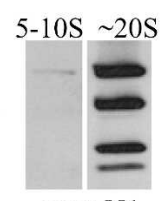

mut-N1

I

FIGURE 5. Functional association of KREN1. Western analysis showing high-resolution glycerol gradient sedimentation profile of tagged KREN1 (N1) $(A)$ and mutated KREN1 (mutN1) (B) complexes purified from cell lysate using IgG column. Lane $T$ represents the TEV elute from IgG column. Protein bands corresponding to KREPA1, KREPA2, KREL1, and KREPA3 are indicated. Fractions from 5 to $10 \mathrm{~S}$ region and $\sim 20 \mathrm{~S}$ region as indicated by line were pooled and purified by Calmodulin affinity column. Western analysis of $\mathrm{N} 1(C)$ and mut-N1 5-10S and $\sim 20 \mathrm{~S}(E)$ complexes, protein bands corresponding to KREPA1, KREPA2, KREL1, and KREPA3 are indicated. Adenylation of N1 $(D)$ and mut-N1 5-10S and $\sim 20 S(F)$ complexes. Adenylated KREL1 and KREL2 are indicated. In vitro precleaved deletion editing $(G)$, precleaved insertion editing $(H)$, deletion endonuclease $(I)$, and insertion endonuclease $(J)$ assays using N1, and mut-N1 5-10S and $\sim 20$ S complexes as indicated. Input RNA (I), edited RNA (E), and ligated $5^{\prime}$ and $3^{\prime}$ RNA in precleaved assays (L), and resulting $3^{\prime}$ cleavage product in endonuclease assay are indicated. In precleaved deletion assay RNA band resulting from removal of 4 U's $(-4 \mathrm{U})$ from $5^{\prime}$ RNA and in precleaved insertion assay by addition of 2 U's $(+2 \mathrm{U})$ to $5^{\prime}$ RNA are indicated.

proteins described here, using several criteria (Panigrahi et al. 2003). The ability to efficiently pull down functional $\sim 20$ S editosomes via a TAP-tag on each of these three proteins provides further evidence that they are part of this catalytic complex. Three additional proteins were identified in editosomes that were purified by at least two different methods. These include KREPA5, which is similar to five other editosome A group of proteins, and KREPB7 and KREPB8, which are similar to KREPB6 and less so to five other editosome B group of proteins (Stuart et al. 2005; A. Schnaufer, unpubl.). Their similarities and physical association with editosomes suggest that they have functional roles in this complex. Most of the 20 proteins identified in $\sim 20$ S editosomes (Table 1 ) occur in pairs or sets based on sequence similarities and/or motifs (Panigrahi et al. 2003; Stuart et al. 2005). The orthologs of all of these proteins were identified in L. major and T. cruzi sequence databases (Worthey et al. 2003; this study) and 14 of these proteins have been identified in TAP-tag purified L. tarentolae complexes (Simpson et al. 2004). Hence, mass spectrometry analysis of editosomes isolated by various methods identified most, but perhaps not all, protein components of the $\sim 20 S T$. brucei editosomes, and these are conserved among kinetoplastids.

\section{Compositional heterogeneity of $20 S$ editosomes}

The different compositions of editosomes isolated by various methods (Panigrahi et al. 2001a,b, 2003), including via different tagged proteins, appear to reflect heterogeneity among $20 \mathrm{~S}$ editosomes. The heterogeneity of RNase III editosomes could conceivably be a consequence of overexpression of each tagged RNase III protein with the abundant protein replacing the other two RNase III proteins in the complex or the tag destabilizing the association of the other RNase III proteins with the complex. However, it seems more likely that the cellular complement of editosomes is normally compositionally heterogeneous. This is supported by the observations that the in vitro deletion endonuclease activity in $20 \mathrm{~S}$ fraction was not affected upon overexpression of KREN1 or KREN2 proteins compared with their respective uninduced cell lines. The knockdown of expression of either endonuclease or exclusive expression of an inactive mutant version of either endonuclease in vivo resulted in cell death and importantly 20 S editosomes that contained the other functional endonuclease were retained at levels similar to those in the wild type (Carnes et al. 2005; Trotter et al. 2005), and the growth rate of cells was not affected by overexpression of either TAP-tagged endonuclease. 
A

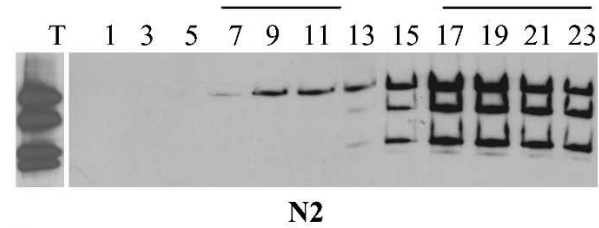

B

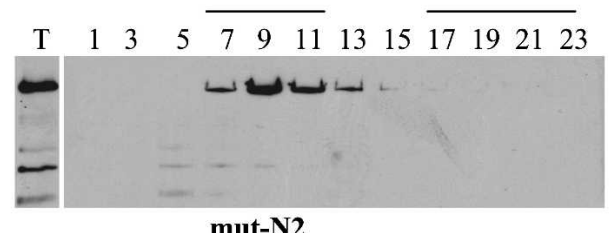

mut-N2

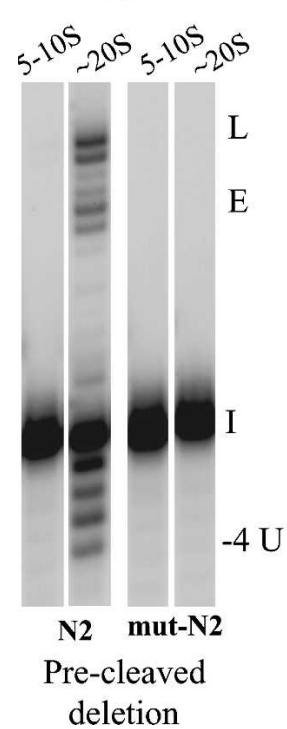

H

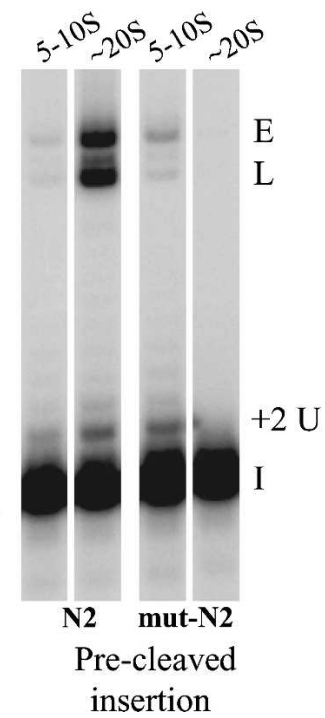

C

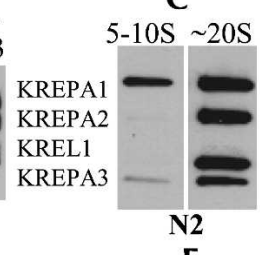

E

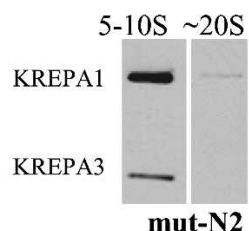

I

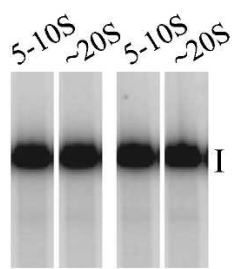

D

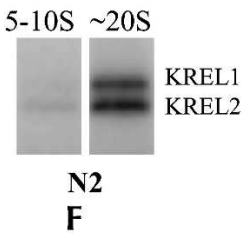

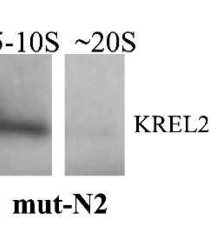

mut-N2

FIGURE 6. Mutations in KREN2 affect structure and function of editosome. Western analysis using MAbs against KREPA1, KREPA2, KREPA3, and KREL1, showing high-resolution glycerol gradient sedimentation profile of tagged KREN2 (N2) $(A)$ and mutated KREN2 (mut-N2) (B) complexes purified from cell lysate using IgG column. Lane $T$ represents the TEV elute from IgG column. Corresponding protein bands are indicated. Fractions from 5 to $10 \mathrm{~S}$ region and $\sim 20 \mathrm{~S}$ region as indicated by line were pooled and purified by Calmodulin affinity column. Western analysis using the MAbs as above of B3 $(C)$ and mut-B3 5-10S and $\sim 20 \mathrm{~S}(E)$ complexes, and corresponding protein bands are indicated. Adenylation of N2 $(D)$ and mut-N2 5-10S and $\sim 20 S(F)$ complexes, showing the presence of adenylated proteins KREL1 and KREL2 as indicated. In vitro assays using N2 and mut-N2 complexes: $(G)$ precleaved deletion editing, $(H)$ precleaved insertion editing, $(I)$ deletion editing endonuclease, and $(J)$ insertion editing endonuclease assays. Input RNA (I), edited RNA (E), and ligated 5' and $3^{\prime}$ RNA in precleaved assays (L), and resulting $3^{\prime}$ cleavage product in endonuclease assay are indicated. In precleaved deletion assay RNA band resulting from removal of 4 U's $(-4 \mathrm{U})$ from $5^{\prime}$ RNA and in precleaved insertion assay by addition of 2 U's (+2 U) to 5' RNA are indicated. N2, mut-N2 5-10S, and $\sim 20$ S complexes as indicated are used in these assays.

complexes. Furthermore, 20S editosomes were present in cells in which only $\sim 10 \mathrm{~S}$ tagged mutated KREN2 editosomes were present.

The biochemically purified editosomes, as well as those purified with monoclonal antibodies specific for KREPA2, are likely to be heterogeneous in composition. This probably reflects nondiscrimination among editosome types by the biochemical isolation procedure and location of KREPA2 in the stable core of the various editosome types, as reflected in their protein content. Detection of KREH1 in these complexes but not in any of the tagged RNase III complexes implies a transient association or association with core complexes with yet other compositions. A similar implication is drawn from the detection of KREPB6 only in complexes that are purified using other tagged editosome proteins (A. Schnaufer and R. Salavati, unpubl.). The fewest proteins were detected in tagged KREPB2 editosomes, suggesting that its composition may be close to that of the stable core. Unlike the other complexes, it does not contain KREPA5, which has sequence similarity to the KREPA6 OBfold protein. Hence, cellular editosomes appear to have compositional heterogeneity, which may involve transient association of proteins that function in editing.

\section{Catalytic components}

Endonucleolytic cleavage of the premRNA at editing site is the first catalytic step in the editing process and is carried out by KREN1 and KREN2 proteins. KREN1 cleaves the pre-mRNA at deletion editing sites from which the KREX1 U specific exonuclease removes the U's to generate a product that is ligated by the KREL1 RNA ligase. SimAdditionally, the knockdown of either endonuclease reduced the amount but not the sedimentation of the editosomes (Carnes et al. 2005; Trotter et al. 2005). Also, KREPB7 and KREPB8 were only detected in the KREN2and KREN1-tagged RNase III complexes, respectively. In addition, both of the $U$ specific exonucleases, KREX1 and KREX2, were detected in tagged KREN1 complexes, but only KREX2 was detected in tagged KREPB2 and KREN2 ilarly, KREN2 cleaves insertion editing sites to which the KRET2 TUTase adds U's to generate a product that is ligated by KREL2 (McManus et al. 2001; Rusché et al. 2001; Schnaufer et al. 2001; Aphasizhev et al. 2003b; Ernst et al. 2003; Palazzo et al. 2003; Carnes et al. 2005; Kang et al. 2005; Trotter et al. 2005). The two T. brucei exonucleases KREX1 and KREX2 may have different, perhaps cooperative, roles in editing. The combined activities of KREN1 
deletion endonuclease and KREX1 U-specific exonuclease are consistent with the KREN1 complexes catalyzing deletion editing, and hence the primary role for KREX1 may be catalyzing removal of U's from deletion sites. An alternative role for KREX2 is suggested by its presence in both KREN1 and KREN2 complexes, possibly trimming excess U's (e.g., added by KRET2). The absence of the presumed C-terminal catalytic domain in Leishmania KREX2 (Worthey et al. 2003; Kang et al. 2005) is consistent with KREX1 having the primary role of $U$ removal and KREX2 an alternative role that may have diverged in Leishmania. Additional studies are needed to resolve the function of these two proteins.

Thus, the catalysts for the six basic steps of insertion and deletion editing have been identified. The function of the KREPB2 RNase III protein has not been identified, but it may function in the cleavage of specific substrates such as CO2 mRNA, which has its guiding sequence in cis. KREPA3 was reported to have endo-exoribonuclease function (Brecht et al. 2005), but we found no correlation with it and in vitro endonuclease or exonuclease activity with the A6 substrates. The three tagged RNAse III complexes and the mutated KREN2 $\sim 10 S$ complex all contained KREPA3 by both Western and mass spectrometry analyses. However, no endonuclease activity was detected with the KREPB2 complexes; only specific insertion or deletion cleavages that were abolished by mutation were detected with the KREN2 and KREN1 complexes, respectively; and no exonuclease activity was detected in the $\sim 10 \mathrm{~S}$ mutated KREN2 complex. Thus, a nucleolytic role for KREPA3 in RNA editing seems unlikely. Its zinc finger and OB-fold motifs imply protein and RNA interaction and perhaps structural or regulatory roles, which is consistent with the enhancement of TUTase and RNA ligase activities upon addition of the recombinant protein to KREPA3 deficient mitochondrial extract (Brecht et al. 2005).

\section{Functional association of RNase III proteins}

The generation of $\sim 10 \mathrm{~S}$ KREN2 complex with two mutated amino acids, which did not occur with mutated KREN1 and KREPB2, indicates that these residues affect interactions between components of the $20 \mathrm{~S}$ editosome and that these interactions differ somewhat between the three RNase III complexes. The $\sim 10 S$ KREN2 complex contained proteins associated with insertion editing consistent with its insertion site cleavage specificity. Thus KREN2 appears stably associated with the KREPA1, KRET2, and KREL2 proteins, which are present in tagged KREL2 insertion editing subcomplex (Schnaufer et al. 2003), plus KREPA3 and KREPA6. Interestingly, the tagged KREPB2 complex also contains these six proteins along with the KREPA2, KREX2, and KREL1 proteins, which are present in the tagged KREL1 deletion editing subcomplex (Schnaufer et al. 2003), plus KREPA4, KREPB4, and KREPB5. Thus, some of these proteins may be shared between or at the interfaces of the insertion and deletion subcomplexes, especially KREPA4 and KREPB5 where inactivation of their expression results in disappearance of $20 \mathrm{~S}$ editosomes (Wang et al. 2003; Salavati et al. 2006). It implies that the most stable core $20 \mathrm{~S}$ editosome may resemble the composition of the KREPB2 complex with either one of the other RNase III proteins being substituted. It appears that KREN1 is physically associated with tagged insertion subcomplex, as is the case with KREN2, although KREN1 is required for deletion endonuclease activity. The KREN1 subcomplex also catalyzes U removal, consistent with KREX1 in tagged KREN1 complexes, implying that KREX1 may be present in the subcomplex. Hence, both KREN1 and KREN2 appear physically associated with the insertion subcomplexes although they cleave deletion or insertion editing sites, respectively. This suggests that all editosome proteins are not physically partitioned into distinct deletion and insertion subcomplexes.

\section{Functional role of RNase III proteins}

The editosome RNase III proteins resemble the class 1 RNase IIIs, which typically function as dimers (Blaszczyk et al. 2001), implying that editosomal RNase IIIs may function as dimers. This could be as homodimers within a single complex or between two or more associated complexes. The presence of both tagged and untagged KREL1 in TAP-tag purified complexes is consistent with the presence of dimers or associated complexes (Aphasizhev et al. 2003a; Schnaufer et al. 2003; Simpson et al. 2004). Unlike classical RNase III enzymes, the editosome RNase IIIs are expected to cleave only the mRNA, specifically at the editing site. Perhaps the editosome RNase IIIs form heterodimers with KREPB4 or KREPB5 that have diverged RNase III motifs, hence providing the specificity for single-stranded cleavage. The dsRNA-binding domain in these proteins may function to recognize the premRNA-gRNA anchor duplex upstream of editing site, thus providing for selection of the cleavage site. In addition, the specific association of KREPB7 and KREPB8 with tagged KREN2 and KREN1 complexes, respectively, implies that they may have regulatory or accessory factor roles that could entail substrate recognition since each has an U1-like zinc finger. Their association appears to be transient or entail low-affinity interactions, since they were detected in biochemically purified editosomes but not in those purified by anti-KREPA2 immunoaffinity chromatography under higher stringency conditions (Panigrahi et al. 2003). The inability to detect endonuclease activity with recombinant (i.e., in vitro transcribed translated) affinity-purified KREN1 or KREN2 protein (A. Panigrahi, unpubl.) may reflect the small amount of protein product, its improper folding, or a requirement for a partner protein(s). While we detected the deletion endonuclease activity in KREN1 
5-10S complexes, the inability to detect the insertion endonuclease activity in the 5-10S tagged KREN2 complexes may be due to insufficient KREN2 protein, absence of a partner protein, and/or functional difference or different structural organization of KREN2 in editosomes compared with KREN1 protein.

The $\sim 20$ S editosome may be quite dynamic since it may interact with other complexes and proteins during editing (Stuart and Panigrahi 2002; Simpson et al. 2004; Stuart et al. 2005). A functional protein-protein interaction map of the 20 S editosome is emerging (Schnaufer et al. 2003), but the data in this paper suggest that its composition may be subject to dynamic variation. The precise composition of the complex that catalyzes editing in vivo is still unknown. There are sequences in pre-edited mRNA with both insertion and deletion editing sites that are specified by a single gRNA. While editing of these sequences may entail association and dissociation of insertion and deletion complexes for each respective site, an alternate possibility is that editosomes similar to the $20 \mathrm{~S}$ editosomes completely edit the sequence specified by the gRNA by a process entailing interchange of the RNase III proteins and others, or entailing higher order complexes containing combinations of KREN1, KREPB2, and KREN2 complexes that may also experience protein interchange. These may be the $40 \mathrm{~S}$ editosomes that were reported previously (Pollard et al. 1992; Corell et al. 1996). Proteins that are not stable components of the 20S editosomes but are associated with other complexes also influence the editing process, e.g., KRET1 TUTase, and RNA binding proteins MRP1 and MRP2, and RBP16 (Allen et al. 1998; Aphasizhev et al. 2002, 2003b; Ernst et al. 2003; Pelletier and Read 2003; Vondruskova et al. 2005). The editosomes may dynamically interact with these complexes as well as other proteins.

\section{MATERIALS AND METHODS}

\section{TAP-tag constructs}

To create vectors for the inducible expression of C-terminally TAP-tagged proteins in T. brucei, the KREN1, KREPB2, and KREN2 ORFs were PCR-amplified from T. brucei (strain 427) genomic DNA and cloned into the pLew79TAP plasmid (Panigrahi et al. 2003). KREN1 ORF was PCR-amplified from T. brucei (strain 427) genomic DNA using primers 4344 (GGATAAAGCTT ATGGGGCTACATTGGC) and 4279 (GGGAGCCATATCGGAT CCCGCACCAACCGAGATGCC) (restriction sites are italicized), digested with HindIII and BamHI enzymes, and cloned into the pLew79TAP plasmid. Similarly, KREPB2 ORF was PCR-amplified with primers 4343 (GGATAAAGCTTATGCGGAACTCGCTCAT TC) and 4280 (GGGAGCCATATCGGATCCGCCGGCCGATTGT GCTAG) and cloned. KREN2 ORF was PCR-amplified in two fragments using primer pairs 4342 (GGATAAAGCTTATGGAGC GCGGAGGGCGC) and 4301 (GTATGACTTCTGGGATGCACA CCGACAG), and 4281 (CTGTCGGTGTGCATCCCAGAAGTCATAC) and 4302 (GGGAGCCATATCGGATCCAACTAATTCGGCCAC
TAGTAGTGC) that incorporated a silent mutation (underlined) to abolish an internal BamHI site. The PCR-amplified fragments were gel-purified, mixed, and used as template to PCR-amplify the full-length ORF using primers 4342 and 4302. The amplified ORF was cloned into the pLew79TAP plasmid as above. This resulted in generation of TAP-KREN1, TAP-KREPB2, and TAPKREN2 plasmids.

Point mutations into TAP-KREN1, TAP-KREPB2, and TAPKREN2 plasmids were incorporated by site-directed mutagenesis, using the QuikChange XL site-directed mutagenesis kit (Stratagene). Primers 4872 (CGTGTGGCGTTCGTAAGATTAGAATA CATCGTTGATAACTCGTGG) and 4873 (CCACGAGTTATCAA CGATGTATTCTAATCTTACGAACGCCACACG) were used to mutagenize KREN1 (the mutagenized codons are underlined). Similarly, primers 4868 (CTGCCCGTTTCGTGAGAAGTGAGAT GATTGTAGATAACATTG) and 4869 (CAATGTTATCTACAAT CATCTCACTTCTCACGAAACGGGCAG) were used for KREPB2, and 4864 (CGTGGGAATTCGTACGTCTCGAATGGATTGTG GATAATGTTGTG) and 4865 (CACAACATTATCCACAATCCA TTCGAGACGTACGAATTCCCACG) were used for KREN2. The sequences of mutagenized constructs were confirmed.

\section{Purification of complexes}

The TAP plasmids from above were linearized with NotI enzyme and transfected into procyclic form (PF) T. brucei cell line 29.13, coexpressing the TET repressor and T7 RNA polymerase. Phleomycin-resistant clones were selected and checked for tetracylineregulated expression. Expression of TAP-tagged proteins was induced for $72 \mathrm{~h}$ with tetracycline $(100 \mathrm{ng} / \mathrm{mL})$, and tagged complexes were purified from 2-5 L of cells harvested at a density of $\sim 2 \times 10^{7}$ cells $/ \mathrm{mL}$ by sequential IgG and Calmodulin affinity chromatography (Rigaut et al. 1999). Tagged complexes were also purified in parallel by sequential IgG affinity followed by glycerol gradient sedimentation and Calmodulin affinity purification as described (Schnaufer et al. 2003) with some modifications. The TEV elute from IgG column was fractionated on $10 \%-30 \%$ glycerol gradient for $14 \mathrm{~h}$ at $38,000 \mathrm{rpm}$ at $4^{\circ} \mathrm{C}$ in SW-40 rotor (Beckman). Fractions from 5 to $10 \mathrm{~S}$ and $20 \mathrm{~S}$ region were pooled separately and further purified by Calmodulin column.

\section{SDS-PAGE and Western blot analysis}

The protein samples were digested with SDS-PAGE loading buffer and resolved on $10 \%$ SDS-PAGE gels. The proteins were stained with SYPRO Ruby stain (Molecular Probes) and detected by fluorescence scanning using PhosphorImager. For Western blot analysis, proteins were separated by SDS-PAGE, transferred onto PVDF membranes, and reacted with MAbs specific for KREPA1, KREPA2, KREL1, and KREPA3 (Panigrahi et al. 2001b). The blots were developed with ECL kit (Amersham) as per manufacturer's instructions. Prestained protein standards were used to determine the size of the bands detected on the blot. Expressed tagged proteins were detected by Western analysis using PAP reagent (Sigma) that is specific to the Protein A moiety of the tag.

\section{Protein and gene identification}

Proteins in editosome samples isolated by tagged KREN1, KREPB2, and KREN2 were separated on 10\% SDS-PAGE gel, and bands 
were visualized by SYPRO Ruby staining. The protein bands were excised from the gel, digested in-gel with trypsin, and identified by mass spectrometry (LC-MS/MS). In parallel isolated editosomes were denatured with $8 \mathrm{M}$ urea and diluted 1:8, the proteins were digested in-solution with trypsin, and the resulting peptides were fractionated and analyzed by tandem mass spectrometry as described (Panigrahi et al. 2001a, b). Similarly, tagged mutant complexes were digested in-solution and analyzed. We also carried out database analysis of the mass spectrometry results obtained in earlier studies (Panigrahi et al. 2003) of column-purified and anti-KREPA2 MAb immunoaffinity-purified editosomes with the updated T. brucei sequence database.

\section{Sequence analysis}

Homology between the proteins was determined by pairwise sequence comparison using EMBOSS, and sequences were aligned using the ClustalW algorithm (http://www.ebi.ac.uk). The protein sequence information was submitted to the GeneDB database for update of the annotations (http://www.genedb.org).

\section{In vitro assays}

RNA ligases (KREL1 and KREL2) were detected by auto-adenylation in the presence of $\left[\alpha-{ }^{32} \mathrm{P}\right]-\mathrm{ATP}$ as described (Sabatini and Hajduk 1995). The proteins were resolved on 10\% SDS-PAGE gels, and the radiolabeled proteins were detected by PhosphorImager. In vitro precleaved deletion editing assay was carried out using $5^{\prime}$ end-labeled U5-5'CL substrate and U5-3'CL RNA with gA6[14]PC-del gRNA as described (Igo et al. 2002). Precleaved insertion editing assay was performed in vitro using $5^{\prime}$ end-labeled substrate 5'CL18 and 3'CL13pp RNA with gRNA gPCA6-2A (Igo et al. 2000). The reaction products were detected by polyacrylamide-urea gel electrophoresis and PhosphorImaging. Modified full-round in vitro insertion RNA editing assay (Kable et al. 1996) was performed using 3'-labeled A6-eES1 pre-mRNA and gA6[14] gRNA in the absence of added adenosine nucleotides to enhance accumulation of the endonuclease cleavage product. A modified full-round deletion editing assay (Seiwert et al. 1996) was performed with 3'-labeled A6short/TAG.1 pre-mRNA and a derivative of D33 gRNA (Cruz-Reyes et al. 2001) called D34 (5'-GGAUAUACUAUAACUCCACCCUCACAACUUUCUU-3') in the presence of $1 \mathrm{mM}$ ADP, no added ATP that enhances endonuclease activity (Cruz-Reyes et al. 1998). These editing assays were carried out using $7 \mu \mathrm{L}$ of samples in each case.

\section{ACKNOWLEDGMENTS}

We thank A. Schnaufer for unpublished data, N. Carmean and A. Larson for technical assistance, Stuart lab members for helpful suggestions, and E. Wirtz and G. Cross for pLew79 plasmid and T. brucei cell line 29.13. Sequence data were obtained from The Institute for Genomic Research (http://www.tigr.org) and The Sanger Centre (http://www.sanger.ac.uk) Web sites. The SBRI mass spectrometer was purchased with funds from NIH grant RR15916, and this work was supported by NIH grant GM042188, which extended work supported by AI014102. Research conducted using equipment made possible by Economic Development Administration-U.S. Department of Commerce and the M.J. Murdock Charitable Trust.
Received January 30, 2006; accepted February 21, 2006.

\section{REFERENCES}

Allen, T.E., Heidmann, S., Reed, R., Myler, P.J., Göringer, H.U., and Stuart, K.D. 1998. Association of guide RNA binding protein gBP21 with active RNA editing complexes in Trypanosoma brucei. Mol. Cell. Biol. 18: 6014-6022.

Aphasizhev, R., Sbicego, S., Peris, M., Jang, S.H., Aphasizheva, I., Simpson, A.M., Rivlin, A., and Simpson, L. 2002. Trypanosome mitochondrial $3^{\prime}$ terminal uridylyl transferase (TUTase): The key enzyme in U-insertion/deletion RNA editing. Cell 108: 637-648.

Aphasizhev, R., Aphasizheva, I., Nelson, R.E., Gao, G., Simpson, A.M., Kang, X., Falick, A.M., Sbicego, S., and Simpson, L. 2003a. Isolation of a U-insertion/deletion editing complex from Leishmania tarentolae mitochondria. EMBO J. 22: 913-924.

Aphasizhev, R., Aphasizheva, I., and Simpson, L. 2003b. A tale of two TUTases. Proc. Natl. Acad. Sci. 100: 10617-10622.

Blaszczyk, J., Tropea, J.E., Bubunenko, M., Routzahn, K.M., Waugh, D.S., Court, D.L., and Ji, X. 2001. Crystallographic and modeling studies of RNase III suggest a mechanism for doublestranded RNA cleavage. Structure 9: 1225-1236.

Brecht, M., Niemann, M., Schlüter, E., Müller, U.F., Stuart, K., and Göringer, H.U. 2005. TbMP42, a protein component of the RNA editing complex in African trypanosomes has endo-exoribonuclease activity. Mol. Cell 17: 621-630.

Carnes, J., Trotter, J.R., Ernst, N.L., Steinberg, A.G., and Stuart, K. 2005. An essential RNAse III insertion editing endonuclease in Trypanosoma brucei. Proc. Natl. Acad. Sci. 102: 16614-16619.

Corell, R.A., Read, L.K., Riley, G.R., Nellissery, J.K., Allen, T.E., Kable, M.L., Wachal, M.D., Seiwert, S.D., Myler, P.J., and Stuart, K.D. 1996. Complexes from Trypanosoma brucei that exhibit deletion editing and other editing-associated properties. Mol. Cell. Biol. 16: 1410-1418.

Cruz-Reyes, J., Rusché, L.N., Piller, K.J., and Sollner-Webb, B. 1998. T. brucei RNA editing: Adenosine nucleotides inversely affect $\mathrm{U}$-deletion and U-insertion reactions at mRNA cleavage. Mol. Cell 1: 401-409.

Cruz-Reyes, J., Zhelonkina, A., Rusche, L., and Sollner-Webb, B. 2001. Trypanosome RNA editing: Simple guide RNA features enhance U deletion 100-fold. Mol. Cell. Biol. 21: 884-892.

Cruz-Reyes, J., Zhelonkina, A.G., Huang, C.E., and Sollner-Webb, B. 2002. Distinct functions of two RNA ligases in active Trypanosoma brucei RNA editing complexes. Mol. Cell. Biol. 22: 4652-4660.

Drozdz, M., Palazzo, S.S., Salavati, R., O'Rear, J., Clayton, C., and Stuart, K. 2002. TbMP81 is required for RNA editing in Trypanosoma brucei. ЕMBO J. 21: 1791-1799.

Ernst, N.L., Panicucci, B., Igo Jr., R.P., Panigrahi, A.K., Salavati, R., and Stuart, K. 2003. TbMP57 is a $3^{\prime}$ terminal uridylyl transferase (TUTase) of the Trypanosoma brucei editosome. Mol. Cell 11: $1525-1536$.

Huang, C.E., Cruz-Reyes, J., Zhelonkina, A.G., O’Hearn, S., Wirtz, E., and Sollner-Webb, B. 2001. Roles for ligases in the RNA editing complex of Trypanosoma brucei: Band IV is needed for U-deletion and RNA repair. EMBO J. 20: $4694-4703$.

Huang, C.E., O'Hearn, S.F., and Sollner-Webb, B. 2002. Assembly and function of the RNA editing complex in Trypanosoma brucei requires band III protein. Mol. Cell. Biol. 22: 3194-3203.

Igo Jr., R.P., Palazzo, S.S., Burgess, M.L.K., Panigrahi, A.K., and Stuart, K. 2000. Uridylate addition and RNA ligation contribute to the specificity of kinteoplastid insertion RNA editing. Mol. Cell. Biol. 20: 8447-8457.

Igo Jr., R.P., Weston, D., Ernst, N., Panigrahi, A.K., Salavati, R., and Stuart, K. 2002. Role of uridylate-specific exoribonuclease activity in kinetoplastid RNA editing. Eukaryot. Cell 1: 112-118.

Kable, M.L., Seiwert, S.D., Heidmann, S., and Stuart, K. 1996. RNA editing: A mechanism for gRNA-specified uridylate insertion into precursor mRNA. Science 273: 1189-1195. 
Kang, X., Falick, A.M., Nelson, R.E., Gao, G., Rogers, K., Aphasizhev, R., and Simpson, L. 2004. Disruption of the zinc finger motifs in the Leishmania tarentolae LC-4 (=TbMP63) Lcomplex editing protein affects the stability of the L-complex. J. Biol. Chem. 279: 3893-3899.

Kang, X., Rogers, K., Gao, G., Falick, A.M., Zhou, S., and Simpson, L. 2005. Reconstitution of uridine-deletion precleaved RNA editing with two recombinant enzymes. Proc. Natl. Acad. Sci. 102: 10171022.

Madison-Antenucci, S. and Hajduk, S. 2001. RNA editing-associated protein 1 is an RNA binding protein with specificity for preedited mRNA. Mol. Cell 7: 879-886.

Madison-Antenucci, S., Grams, J., and Hajduk, S.L. 2002. Editing machines: The complexities of trypanosome RNA editing. Cell 108: $435-438$.

McManus, M.T., Shimamura, M., Grams, J., and Hajduk, S.L. 2001. Identification of candidate mitochondrial RNA editing ligases from Trypanosoma brucei. RNA 7: 167-175.

Müller, U.F., Lambert, L., and Göringer, H.U. 2001. Annealing of RNA editing substrates facilitated by guide RNA-binding protein gBP21. EMBO J. 20: 1394-1404.

O'Hearn, S., Huang, C.E., Hemann, M., Zhelonkina, A., and SollnerWebb, B. 2003. Trypanosoma brucei RNA editing complex: Band II is structurally critical and maintains band V ligase, which is nonessential. Mol. Cell. Biol. 23: 7909-7919.

Palazzo, S.S., Panigrahi, A.K., Igo Jr., R.P., Salavati, R., and Stuart, K. 2003. Kinetoplastid RNA editing ligases: Complex association, characterization, and substrate requirements. Mol. Biochem. Parasitol. 127: 161-167.

Panigrahi, A.K., Gygi, S., Ernst, N., Igo Jr., R.P., Palazzo, S.S., Schnaufer, A., Weston, D., Carmean, N., Salavati, R., Aebersold, R., et al. 2001a. Association of two novel proteins, TbMP52 and TbMP48, with the Trypanosoma brucei RNA editing complex. Mol. Cell. Biol 21: 380-389.

Panigrahi, A.K., Schnaufer, A., Carmean, N., Igo Jr., R.P., Gygi, S.P., Ernst, N.L., Palazzo, S.S., Weston, D.S., Aebersold, R., Salavati, R., et al. 2001b. Four related proteins of the Trypanosoma brucei RNA editing complex. Mol. Cell. Biol. 21: 6833-6840.

Panigrahi, A.K., Schnaufer, A., Ernst, N.L., Wang, B., Carmean, N., Salavati, R., and Stuart, K. 2003. Identification of novel components of Trypanosoma brucei editosomes. RNA 9: 484-492.

Pelletier, M. and Read, L.K. 2003. RBP16 is a multifunctional gene regulatory protein involved in editing and stabilization of specific mitochondrial mRNAs in Trypanosoma brucei. RNA 9: 457-468.

Pollard, V.W., Harris, M.E., and Hajduk, S.L. 1992. Native mRNA editing complexes from Trypanosoma brucei mitochondria. EMBO J. 11: 4429-4438.

Rigaut, G., Shevchenko, A., Rutz, B., Wilm, M., Mann, M., and Seraphin, B. 1999. A generic protein purification method for protein complex characterization and proteome exploration. Nat. Biotechnol. 17: 1030-1032.

Rusché, L.N., Cruz-Reyes, J., Piller, K.J., and Sollner-Webb, B. 1997. Purification of a functional enzymatic editing complex from Trypanosoma brucei mitochondria. EMBO J. 16: 4069-4081.

Rusché, L.N., Huang, C.E., Piller, K.J., Hemann, M., Wirtz, E., and Sollner-Webb, B. 2001. The two RNA ligases of the Trypanosoma brucei RNA editing complex: Cloning the essential Band IV gene and identifying the Band V gene. Mol. Cell. Biol. 21: 979-989.

Sabatini, R. and Hajduk, S.L. 1995. RNA ligase and its involvement in guide RNA/mRNA chimera formation. Evidence for a cleavageligation mechanism of Trypanosoma brucei mRNA editing. J. Biol. Chem. 270: 7233-7240.

Salavati, R., Ernst, N.L., O'Rear, J., Gilliam, T., Tarun Jr., S., and Stuart, K. 2006. KREPA4, an RNA binding protein essential for editosome integrity and survival of Trypanosoma brucei. RNA (in press).

Schnaufer, A., Panigrahi, A.K., Panicucci, B., Igo Jr., R.P., Salavati, R., and Stuart, K. 2001. An RNA ligase essential for RNA editing and survival of the bloodstream form of Trypanosoma brucei. Science 291: 2159-2162.

Schnaufer, A., Ernst, N., O'Rear, J., Salavati, R., and Stuart, K. 2003. Separate insertion and deletion sub-complexes of the Trypanosoma brucei RNA editing complex. Mol. Cell 12: 307-319.

Seiwert, S.D., Heidmann, S., and Stuart, K. 1996. Direct visualization of uridylate deletion in vitro suggests a mechanism for kinetoplastid RNA editing. Cell 84: 831-841.

Simpson, L., Aphasizhev, R., Gao, G., and Kang, X. 2004. Mitochondrial proteins and complexes in Leishmania and Trypanosoma involved in U-insertion/deletion RNA editing. RNA 10: 159-170.

Stuart, K. and Panigrahi, A.K. 2002. RNA editing: Complexity and complications. Mol. Microbiol. 45: 591-596.

Stuart, K.D., Schnaufer, A., Ernst, N.L., and Panigrahi, A.K. 2005. Complex management: RNA editing in trypanosomes. Trends Biochem. Sci. 30: 97-105.

Trotter, J.R., Ernst, N.L., Carnes, J., Panicucci, B., and Stuart, K. 2005. A deletion site editing endonuclease in Trypanosoma brucei. Mol. Cell 20: 403-412.

Vondruskova, E., Van den Burg, J., Zikova, A., Ernst, N.L., Stuart, K., Benne, R., and Lukes, J. 2005. RNA interference analyses suggest a transcript-specific regulatory role for MRP1 and MRP2 in RNA editing and other RNA processing in Trypanosoma brucei. J. Biol. Chem. 280: 2429-2438.

Wang, B., Ernst, N., Palazzo, S.S., Panigrahi, A.K., Salavati, R., and Stuart, K. 2003. TbMP44 is essential for RNA editing and structural inegrity of the editosome in Trypanosoma brucei. Eukaryot. Cell 2: 578-587.

Worthey, E.A., Schnaufer, A., Mian, I.S., Stuart, K., and Salavati, R. 2003. Comparative analysis of editosome proteins in trypanosomatids. Nucleic Acids Res. 31: 6392-6408. 

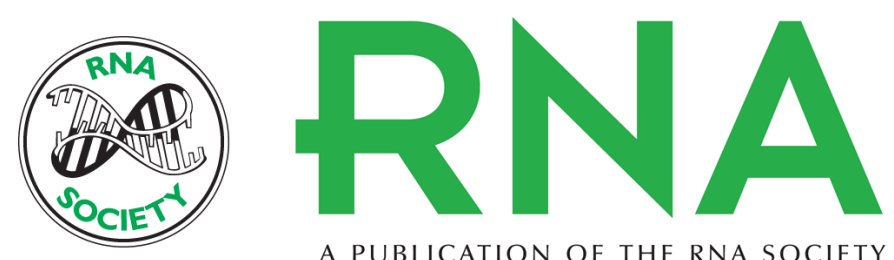

A PUBLICATION OF THE RNA SOCIETY

\section{Compositionally and functionally distinct editosomes in Trypanosoma brucei}

Aswini K. Panigrahi, Nancy Lewis Ernst, Gonzalo J. Domingo, et al.

RNA 2006 12: 1038-1049

References This article cites 45 articles, 28 of which can be accessed free at:

http://rnajournal.cshlp.org/content/12/6/1038.full.html\#ref-list-1

License

Email Alerting Receive free email alerts when new articles cite this article - sign up in the box at the Service top right corner of the article or click here.

To subscribe to RNA go to:

http://rnajournal.cshlp.org/subscriptions 